\title{
Mathematical models for prediction of rheological parameters in vinasses derived from sugar cane**
}

\author{
Leidy M. Chacua ${ }^{1}$, Germán Ayala ${ }^{2 *}$, Hernán Rojas ${ }^{1}$, and Ana C. Agudelo ${ }^{1}$ \\ ${ }^{1}$ Faculty of Engineering and Administration, National University of Colombia, Palmira campus, AA 237, Colombia \\ ${ }^{2}$ Faculty of Animal Science and Food Engineering, University of São Paulo, Av. Duque de Caxias Norte 225, \\ 13635-000, Pirassununga, SP, Brazil \\ Received September 3, 2015; accepted February 22, 2016
}

\begin{abstract}
A b s t r a c t. The rheological behaviour of vinasses derived from sugar cane was studied as a function of time (0 and $600 \mathrm{~s})$, soluble solids content (44 and $60{ }^{\circ}$ Brix), temperature (10 and $\left.50^{\circ} \mathrm{C}\right)$, and shear rate $\left(0.33\right.$ and $\left.1.0 \mathrm{~s}^{-1}\right)$. The results indicated that vinasses were time-independent at $25^{\circ} \mathrm{C}$, where shear stress values ranged between 0.01 and $0.08 \mathrm{~Pa}$. Flow curves showed a shear-thinning rheological behaviour in vinasses with a flow behaviour index between 0.69 and 0.89 , for temperature between 10 and $20^{\circ} \mathrm{C}$. With increasing temperature, the flow behaviour index was modified, reaching values close to 1.0. The Arrhenius model described well the thermal activation of shear stress and the consistency coefficient as a function of temperature. Activation energy from the Arrhenius model ranged between 31 and $45 \mathrm{~kJ}$ $\mathrm{mol}^{-1}$. Finally, the consistency coefficient as a function of the soluble solids content and temperature was well fitted using an exponential model $\left(\mathrm{R}^{2}=0.951\right)$, showing that the soluble solids content and temperature have an opposite effect on consistency coefficient values.

K e y w or d s: ethanol industry, vinasses, pseudoplastic, rheological models
\end{abstract}

\section{INTRODUCTION}

Vinasses are organic residues in the liquid state produced by ethanol industry; they are generated in a proportion of approximately 12-15 1 for each litre of alcohol produced (Lozano et al., 2010; Santos et al., 2013). The properties of vinasses depend on the raw material used for ethanol production, thus vinasses derived from maize, barley, and wheat have a high quantity of insoluble solids; in contrast, vinasses derived from sugarcane, sugar beet, grape, agave, or sweet sorghum have a high proportion of soluble solids

*Corresponding author e-mail: gayalav1230@gmail.com

**This work was supported by National University of Colombia, Palmira campus, DIPAL code number QUIPU 2020100626, and the Environmental Research Laboratory, National University of Colombia, Palmira campus, 2013.
(Gamboa et al., 2011). In general, vinasses are characterized by having a dark brown colour, $\mathrm{pH}$ between 3.5-5.0, high organic content, and chemical oxygen demand values between 50-150 $\mathrm{g} \mathrm{l}^{-1}$ (Gamboa et al., 2011).

Regularly, vinasses are directly disposed of in the environment. Particularly, they are used as a fertilizer due to the high concentration of potassium and calcium, as well as their high organic content (Gamboa et al., 2011; Prasad et al., 2008). However, it is well accepted that vinasses can pollute soil and groundwater due to their high organic content and dissolved solids. In addition, this residue has phytotoxic, antibacterial, and recalcitrant compounds that can alter the ecosystem (Gamboa et al., 2011).

Knowledge of rheological properties of vinasses is very important, because it can be used for different engineering applications such as equipment design, designing of transport system, pump capacity design, and power requirements for mixing (Dak et al., 2008a). Shear-thinning properties of biological systems are frequently characterized by means of shear stress vs. shear rate rheological tests, which are used to characterize rheological parameters such as yield stress $\left(\tau_{\mathrm{o}}\right)$, consistency coefficient $(K)$, and flow behaviour index (n) (Chaves et al., 2013). Understanding flow properties of vinasses, at different concentrations and temperature, could help to improve vinasse disposal in ethanol industry.

A limited number of investigations are reported in literature about the rheology properties of vinasses. Lozano et al. (2010) studied the effect of temperature $\left(20-35^{\circ} \mathrm{C}\right)$ on the rheological properties in vinasses. No information about vinasse solids content was provided in this report. The authors reported a non-Newtonian behaviour in vinasses that were well fitted to the Herschel-Bulkley model. For all

(C) 2016 Institute of Agrophysics, Polish Academy of Sciences 
fits, the yield stress $\left(\tau_{\mathrm{o}}\right)$ ranged between $0.09-0.11 \mathrm{~Pa}$, and the flow behaviour index $(n)$ varied between 1.0 and 1.1. Perez et al. (2000) also studied the rheological behaviour of vinasses at different soluble solids content (31-73 $\left.{ }^{\circ} \mathrm{Brix}\right)$ and temperatures $\left(22-90^{\circ} \mathrm{C}\right)$. The authors reported a seconddegree polynomial dependence between the apparent viscosity and temperature; they did not report pseudoplastic rheological models.

This study aims to characterize the structural, and rheological properties of vinasses, reporting a more detailed analysis, related to their dependence on the soluble solids content, shear rate, and temperature.

\section{MATERIALS AND METHODS}

A vinasse sample with soluble solids content (SSC) of $42^{\circ}$ Brix was obtained directly from sugar cane industry in the state of Valle del Cauca (Colombia).

The chemical composition was determined in vinasse raw material with a $\mathrm{SSC}=42^{\circ}$ Brix. Water content, ash, and crude fat were determined using the AOAC methods (AOAC, 1990a, 1990b, 1990c). Crude protein was examined using the Kjeldahl method and using a conversion factor of 6.25 (Kjeldahl, 1883). Crude fibre was analyzed by means of the Van Soest method (Soest and Wine, 1967). Total carbohydrate content was calculated by weight difference. Chemical determinations were performed at least twice.

Firstly, vinasse $\left(42^{\circ} \mathrm{Brix}\right)$ was concentrated by the heating process at $100^{\circ} \mathrm{C}$ to obtain vinasse concentrations at 44 , 47,50 , and $60 \pm 0.2^{\circ} \mathrm{Brix}$. The soluble solids content ( ${ }^{\circ} \mathrm{Brix}$ ) was determined using a refractometer (ATAGO HRS-500, Tokyo, Japan).

Light microscopy (LM) characterization was performed in vinasses $\left(44,47,50\right.$, and $60 \pm 0.2^{\circ}$ Brix). Samples were placed directly on the microscope (Zeiss, AxioLab. A1, Oberkochen, Germany) and then obeserved at two magnification levels, 20x and 40x. Images were captured with an AxioCam (ICc1, ZEN-2, Oberkochen, Germany) and they were analysed using software ImageJ v 1.39 (National Institute Health, Bethesda, MD, USA).

The rheological properties of the vinasses $(44,47,50$, and $60 \pm 0.2^{\circ}$ Brix) were measured using a viscometer (DV-E Brookfield, Middleboro, MA, USA). Firstly, the shear stress $(\tau)$ was measured as a function of time $(600 \mathrm{~s})$ at $25^{\circ} \mathrm{C}$. Secondly, the shear stress $(\tau)$ was measured as a function of the shear rate $(\dot{\gamma})$, which was increased from 0.33 to $1.0 \mathrm{~s}^{-1}$. For this rheological test, vinasses were loaded into a cylindrical cup and conditioned in a water bath at specific temperature $\left(10,20,30,40\right.$, and $\left.50 \pm 1{ }^{\circ} \mathrm{C}\right)$. All rheological tests were performed using a spindle type S-61 and five hundred millilitres of vinasse. All analyses were realized at least three times using the Brookfield viscometer between $10-90 \%$ full torque scales.
An analysis of variance (ANOVA) and Tukey test of multiple comparisons were accomplished with a significance level of 5\% (SAS software, version 9.2). All fitting curves were done using MS-Excel software ${ }^{\circledR}$, Origin (version 6.1) and Statistica (version 10.0).

\section{RESULTS AND DISCUSSION}

Vinasse had a chemical composition as follows: water content $(19.30 \%)$, ash $(19.52 \%)$, crude protein $(6.05 \pm$ $0.64 \%)$, crude fat $(0.11 \%)$, crude fiber $(0.47 \%)$, and carbohydrate contents $(74.52 \%)$. The ash and protein contents in vinasse are similar to those reported previously by Cortez and Pérez (1997) and Ahmed et al. (2013).

According to Ahmed et al. (2013), the chemical composition of vinasse is variable and depends on the raw material used for ethanol production, as well as alcoholic fermentation, types of yeast, and the distillation and separation industrial processes.

Light microscopy micrographs of vinasses were studied at two magnification levels (Fig. 1). At the smaller magnification (Fig. 1a, c, e, g), it can be seen that the particle number increased with the SSC. In addition, at the higher magnification (Fig. 1b, d, f, h), it was observed that the particle size was not altered with SSC. Hence, two particle sizes were observed: the first particle size between 4-13 $\mu \mathrm{m}$ and the second particle size between $90-130 \mu \mathrm{m}$. These results indicated that the heating process led to water evaporation but did not alter the particle size.

The time-dependence revealed a strong effect of SSC on shear stress values (Fig. 2). Hence, higher shear stress values were obtained in vinasses with $\mathrm{SSC}=60^{\circ}$ Brix. The shear stress values in vinasses were significantly different $(\mathrm{p}<0.05)$, except for vinasses with $\mathrm{SSC}=44$ and $47^{\circ}$ Brix, where insignificant differences were registered $(p>0.05)$. More importantly, these results indicate that all samples achieved an instantaneous equilibrium condition, where the shear stress values were not altered during the time of analysis $(600 \mathrm{~s})$. No alteration of shear stress $v s$. time is frequently reported in systems without thixotropic behaviour (Juszczak et al., 2012).

The flow curves of vinasses showed a non-linear increase in shear stress as a function of shear rate (Fig. 3). Based on least-square analysis of the corresponding data, the shear stress vs. shear rate curves were well fitted to the power law model $\left(0.991<\mathrm{R}^{2}<1.0\right)$ :

$$
\tau=K \dot{\gamma}^{n},
$$

where: $\tau$ is the shear stress $(\mathrm{Pa}), K$ is the consistency coefficient $\left(\mathrm{Pa} \mathrm{s}^{\mathrm{n}}\right)$, function of the shear rate $(\dot{\gamma})$, and $n$ is the flow behaviour index (dimensionless).

Parameters from the power law model are reported in Table 1 . The flow curves in vinasses were characterized by having two rheological behaviours. Firstly, a pseudoplastic or shear-thinning behaviour $(0.69 \leq n \leq 0.89)$ was observed 


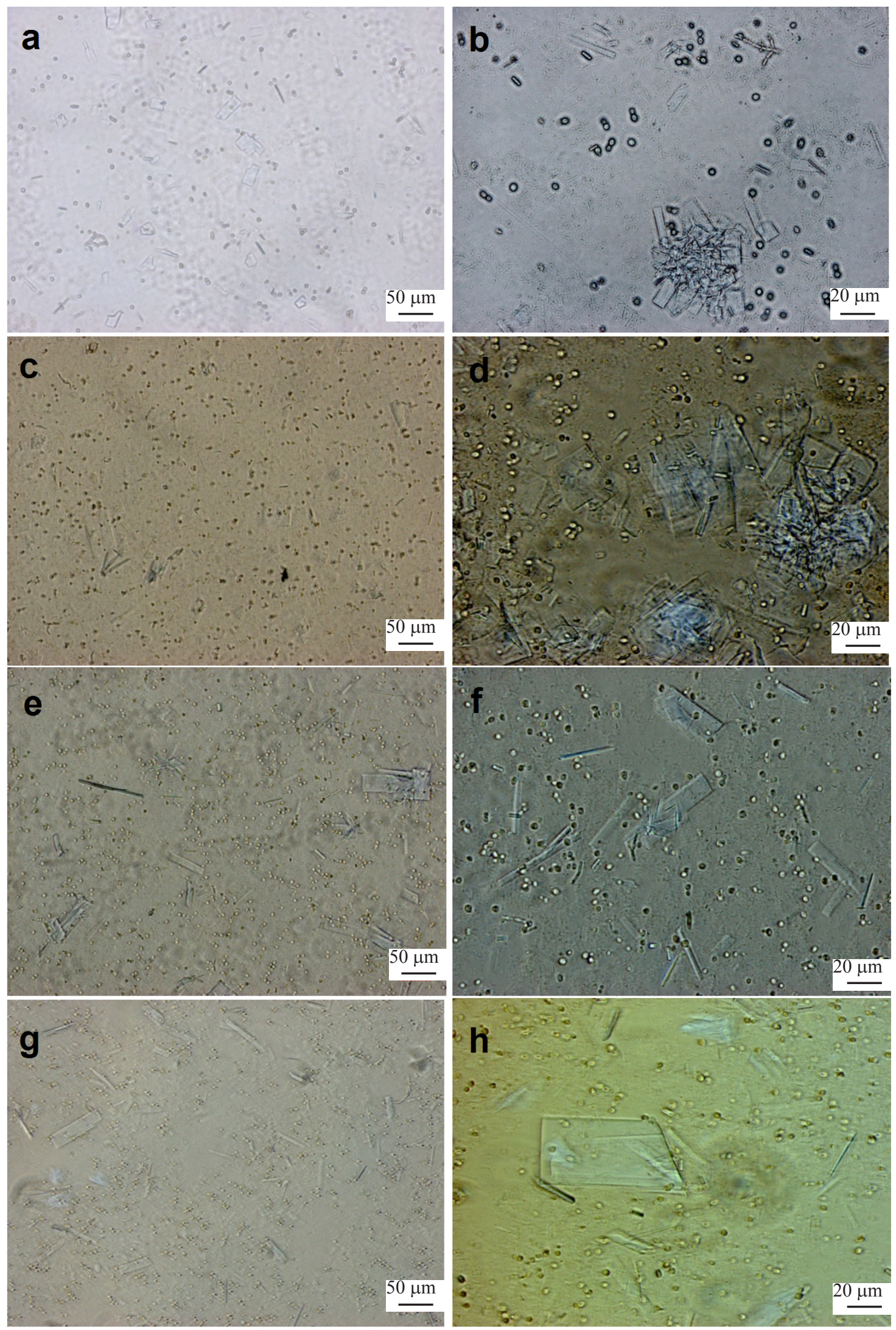

Fig. 1. Micrographs of vinasses with soluble solids content of: $a, b-44^{\circ}$ Brix; $c, d-47^{\circ}$ Brix; $e, f-50^{\circ}$ Brix; and $g, h-60^{\circ}$ Brix. Photos were collected at two different magnifications. 


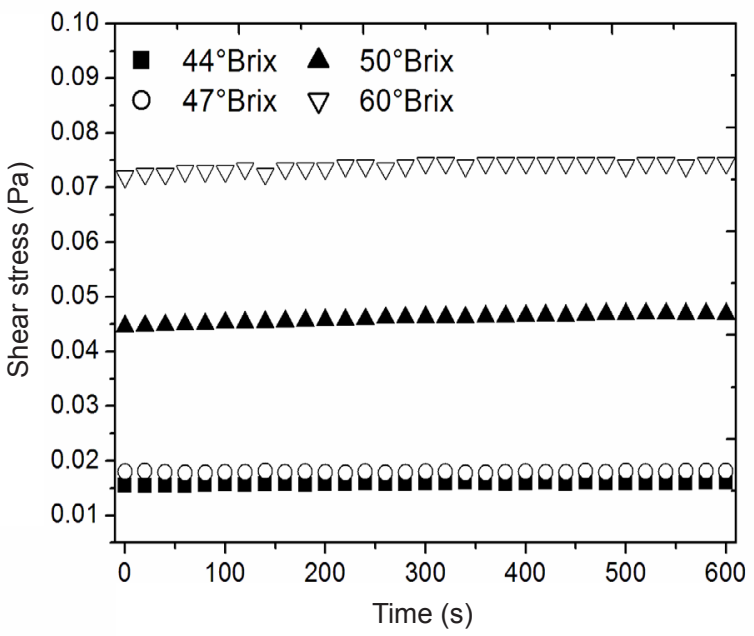

Fig. 2. Time-dependent shear stress values at $20^{\circ} \mathrm{C}$ of vinasses with different soluble solids content.

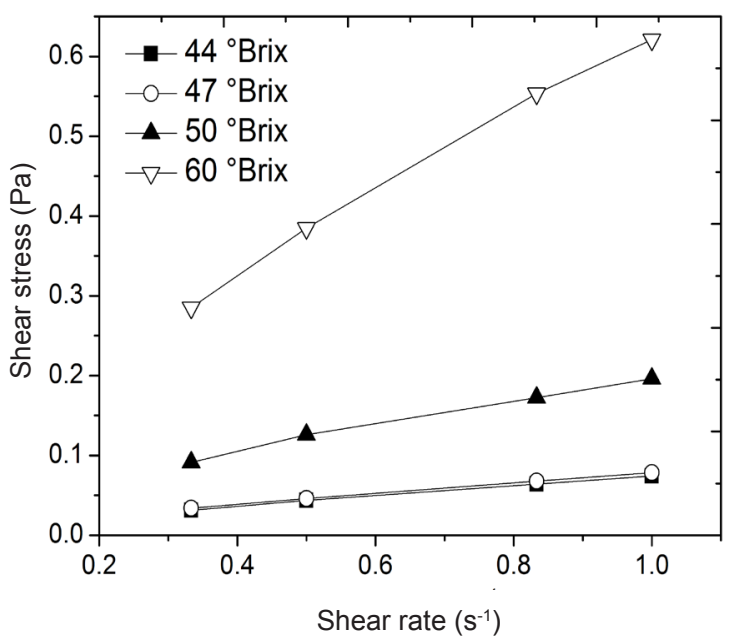

Fig. 3. Shear stress $v s$. shear rate values of vinasses with different soluble solids content.

T a b l e 1. Fitting parameters $K$ and $n$ from power law model for vinasses at different soluble solids content

\begin{tabular}{ccccccc}
\hline & & \multicolumn{5}{c}{ Temperature $\left({ }^{\circ} \mathrm{C}\right)$} \\
\cline { 3 - 7 } Parameter & SSC $\left({ }^{\circ} \mathrm{Brix}\right)$ & 10 & 20 & 30 & 40 & 50 \\
\hline & 44 & $0.07 \pm 0.01 \mathrm{~B}, \mathrm{a}$ & $0.04 \pm 0.01 \mathrm{C}, \mathrm{b}$ & $0.03 \pm 0.01 \mathrm{C}, \mathrm{bc}$ & $0.02 \pm 0.00 \mathrm{~B}, \mathrm{c}$ & $0.01 \pm 0.00 \mathrm{C}, \mathrm{c}$ \\
& 47 & $0.08 \pm 0.01 \mathrm{~B}, \mathrm{a}$ & $0.06 \pm 0.00 \mathrm{C}, \mathrm{b}$ & $0.03 \pm 0.00 \mathrm{C}, \mathrm{c}$ & $0.02 \pm 0.00 \mathrm{~B}, \mathrm{c}$ & $0.02 \pm 0.00 \mathrm{C}, \mathrm{c}$ \\
& 50 & $0.20 \pm 0.03 \mathrm{~B}, \mathrm{a}$ & $0.15 \pm 0.01 \mathrm{~B}, \mathrm{a}$ & $0.08 \pm 0.00 \mathrm{~B}, \mathrm{~b}$ & $0.05 \pm 0.01 \mathrm{~B}, \mathrm{~b}$ & $0.04 \pm 0.01 \mathrm{~B}, \mathrm{~b}$ \\
& 60 & $0.62 \pm 0.14 \mathrm{~A}, \mathrm{a}$ & $0.40 \pm 0.02 \mathrm{~A}, \mathrm{ab}$ & $0.18 \pm 0.02 \mathrm{~A}, \mathrm{bc}$ & $0.11 \pm 0.04 \mathrm{~A}, \mathrm{c}$ & $0.08 \pm 0.01 \mathrm{~A}, \mathrm{c}$ \\
& & & & & & \\
& 44 & $0.79 \pm 0.01$ & $0.89 \pm 0.11$ & $1.09 \pm 0.12$ & $1.12 \pm 0.05$ & $1.07 \pm 0.26$ \\
& 47 & $0.76 \pm 0.09 \mathrm{~b}$ & $0.75 \pm 0.03 \mathrm{~b}$ & $0.98 \pm 0.04 \mathrm{ab}$ & $0.96 \pm 0.02 \mathrm{ab}$ & $1.11 \pm 0.18 \mathrm{ab}$ \\
& 50 & $0.69 \pm 0.04 \mathrm{~b}$ & $0.70 \pm 0.04 \mathrm{~b}$ & $0.95 \pm 0.01 \mathrm{a}$ & $0.94 \pm 0.01 \mathrm{a}$ & $0.88 \pm 0.10 \mathrm{a}$ \\
& 60 & $0.71 \pm 0.02 \mathrm{~b}$ & $0.74 \pm 0.09 \mathrm{~b}$ & $1.02 \pm 0.11 \mathrm{a}$ & $1.01 \pm 0.13 \mathrm{a}$ & $0.93 \pm 0.04 \mathrm{ab}$ \\
\hline
\end{tabular}

SSC - soluble solids content, $K$ - consistency coefficient, $n$ - flow behavior index. Means within the same column (for the same rheological parameter) having different capital letter are significantly different at $p<0.05$. Means within the same row having different lowercase letter are significantly different at $\mathrm{p}<0.05$. All values were expressed as mean $\pm \operatorname{standard}$ deviation $(n=3)$.

in vinasses for temperatures between 10 and $20^{\circ} \mathrm{C}$. Secondly, with an increase in temperature ( $T=30,40$ and $50^{\circ} \mathrm{C}$ ), it was observed that the $n$ values were close to 1.0 , indicating an approach to the Newtonian model $(\tau=\eta \dot{\gamma})$. The consistency coefficient was altered by SSC and temperature $(\mathrm{p}<0.05)$. In addition, the flow behaviour index only was altered by temperature $(\mathrm{p}<0.05)$, except for the vinasse sample with $\mathrm{SSC}=44^{\circ} \mathrm{Brix}$. Low temperatures $(T=10$ and $20^{\circ} \mathrm{C}$ ) promoted the formation of hydrogen bonds between macromolecules-macromolecules and macromoleculeswater, hence, the non-linear increase in shear stress as a function of the shear rate was due to the breakdown of structural units caused by hydrodynamic forces generated during cutting (Grigelmo et al., 1999; Nurul et al., 1999; Valencia et al., 2013). High temperatures, such as $T=30,40$, and $50^{\circ} \mathrm{C}$ promoted the breakdown of weak interactions (hydrogen bonds) between macromoleculesmacromolecules and macromolecules-water, obtaining a rheological behaviour typical of liquid systems (Grigelmo et al., 1999). For the same temperature, the increase in SSC led to an increase in shear stress values caused by a higher proportion in hydrated macromolecules and hydrogen bonding with the hydroxyl groups of solutes (Manjuantha 
T a b l e 2. Fitting parameters $\tau_{\mathrm{o}}$ and $E_{a}$ from Arrhenius model for vinasses at different shear rates

\begin{tabular}{ccccc}
\hline SSC $\left({ }^{\circ}\right.$ Brix $)$ & Shear rate $\left(\mathrm{s}^{-1}\right)$ & $\tau_{\mathrm{o}}(\mathrm{Pa})$ & $E_{a}\left(\mathrm{~kJ} \mathrm{~mol}^{-1}\right)$ & $\mathrm{R}^{2}$ \\
\hline 0.33 & $310^{-9}$ & 37.71 & 0.984 \\
\hline 44 & $110^{-8}$ & 35.62 & 0.980 \\
& 0.50 & $610^{-8}$ & 32.69 & 0.988 \\
& 1.00 & $110^{-7}$ & 31.36 & 0.989 \\
& 0.33 & $810^{-9}$ & 36.00 & 0.963 \\
47 & 0.50 & $510^{-8}$ & 32.29 & 0.964 \\
& 0.83 & $210^{-7}$ & 29.54 & 0.972 \\
& 1.00 & $410^{-7}$ & 28.57 & 0.972 \\
& 0.33 & $210^{-8}$ & 36.39 & 0.858 \\
50 & 0.50 & $410^{-8}$ & 35.18 & 0.881 \\
& 0.83 & $210^{-7}$ & 32.34 & 0.894 \\
& 1.00 & $310^{-7}$ & 31.51 & 0.897 \\
& 0.33 & $210^{-9}$ & 44.88 & 0.960 \\
& 0.50 & $310^{-9}$ & 44.45 & 0.940 \\
& 0.83 & $110^{-8}$ & 41.45 & 0.937 \\
& 1.00 & $410^{-8}$ & 39.56 & 0.938 \\
\hline
\end{tabular}

$\mathrm{SSC}$ - soluble solids content, $\tau_{\mathrm{o}}$ - constant parameter, $E_{a}$ - activation energy, $\mathrm{R}^{2}$ - coefficient of determination.

et al., 2012). Previously, Lozano et al. (2010) reported the pseudoplastic behaviour in vinasses, and these systems were well fitted to the Hesrchel-Bulkley equation, reporting $n$ values between 1.01 and 1.10 .

For a shear rate constant, the shear stress $(\tau)$ decreases exponentially with the temperature and it was well fitted to the Arrhenius model:

$$
\tau=\tau_{\mathrm{o}} \exp \left(\frac{E_{a}}{R T}\right),
$$

where: $\tau_{\mathrm{o}}$ is a constant parameter $(\mathrm{Pa}), E_{a}$ is the activation energy $\left(\mathrm{kJ} \mathrm{mol}^{-1}\right), R$ is the universal constant gas $(8.314 \mathrm{~J}$ $\mathrm{mol}^{-1} \mathrm{~K}^{-1}$ ) and $T$ is the absolute temperature (K) (Rao et al., 1997).

The parameters from the Arrhenius model of shear stress $v s$. temperature are reported in Table 2. Activation energy indicates sensitivity of the shear stress to temperature changes. Higher activation energy means that the shear stress is relatively more sensitive to the temperature (Quek et al., 2013). For the same SSC, it is clear that the shear stress values were more sensitive to the temperature changes when low shear rates were applied (Fig. 4 and Table 2). This result suggests that the shear rate promoted the rupture of weak interactions such as hydrogen bonds in vinasses.
High shear rates ie 0.83 and $1.00 \mathrm{~s}^{-1}$, led to small differences in activation energy values in vinasses with different SSC (Table 2). This result suggests the existence of a shear rate limit, surpassing this limit, and shear stress values are only influenced by temperature modifications. The existence of a shear rate limit is an important result to be used in industrial equipment design (eg agitator, heat exchanger), and designing of vinasse transport and pump capacity (Dak et al., 2008a).

Similarly, the consistency coefficient decreased exponentially with the temperature and it was well fitted to the Arrhenius model:

$$
K=\mathrm{K}_{\mathrm{o}} \exp \left(\frac{E_{a}}{R T}\right)
$$

where $\mathrm{K}_{\mathrm{o}}$ is a constant parameter $\left(\mathrm{Pa} \mathrm{s} \mathrm{s}^{\mathrm{n}}\right)$.

For vinasses with SSC between 44 and $50^{\circ}$ Brix, the activation energy remained constant (Fig. 5, Table 3), indicating the same thermal sensitivity for the systems. However, for vinasses with $\mathrm{SSC}=60^{\circ}$ Brix, the $E_{a}$ value increased, indicating a higher thermal sensitivity of the system. High SSC $\left(60^{\circ}\right.$ Brix $)$ promoted high hydrogen bonds between macromolecules-macromolecules and macromolecules-water, resulting in an increase in consistency. In addition, these interactions were more sensitive with 


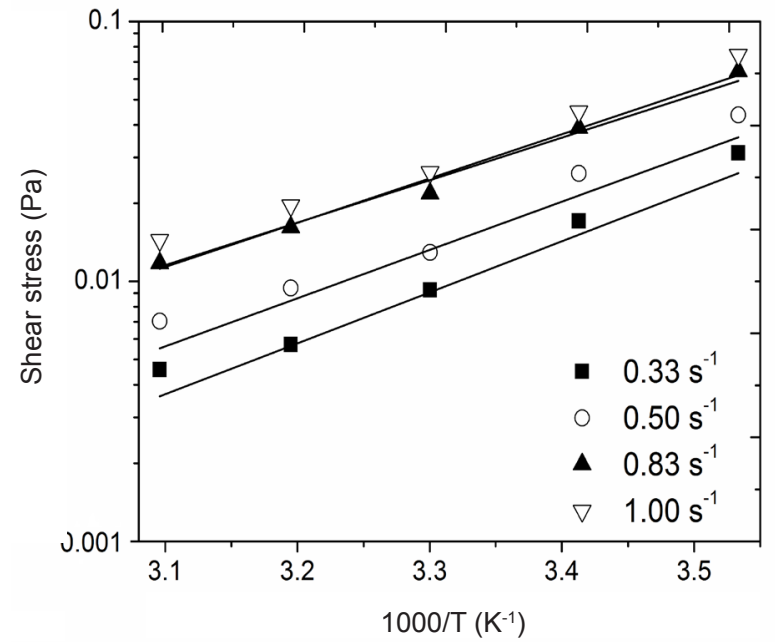

Fig. 4. Effect of temperature on the shear stress values of vinasse $\left(44^{\circ}\right.$ Brix) at different shear rates $\left(\mathrm{s}^{-1}\right)$. The continuous lines are exponential fits to the Arrhenius model.

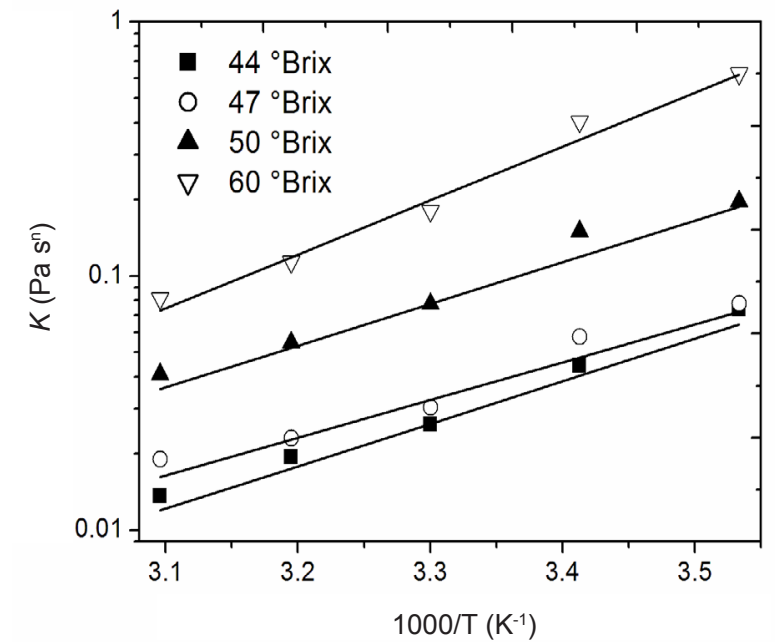

Fig. 5. Effect of temperature on the consistency coefficient $(K)$ of vinasses. The continuous lines are exponential fits to the Arrhenius model.

T a b l e 3. Fitting parameters $K_{o}$ and $E_{a}$ from Arrhenius model for vinasses at different soluble solids content

\begin{tabular}{cccc}
\hline SSC $\left({ }^{\circ}\right.$ Brix $)$ & $\mathrm{K}_{0}\left(\mathrm{~Pa} \mathrm{~s}^{\mathrm{n}}\right)$ & $E_{a}\left(\mathrm{~kJ} \mathrm{~mol}^{-1}\right)$ & $\mathrm{R}^{2}$ \\
\hline 44 & $810^{-8}$ & 32.09 & 0.992 \\
47 & $410^{-7}$ & 28.57 & 0.969 \\
50 & $310^{-7}$ & 31.49 & 0.980 \\
60 & $210^{-8}$ & 40.70 & 0.984 \\
\hline
\end{tabular}

$\mathrm{SSC}$ - soluble solids content, $\mathrm{K}_{\mathrm{o}}$ - constant parameter, $E_{a}$ - activation energy, $\mathrm{R}^{2}$ - coefficient of determination.

temperature modifications. Similar behaviour was reported in food systems such as tomato concentrate, pineapple juice, enzyme clarified Indian gooseberry juice, and sugar cane syrups (Dak et al., 2008a,b; Mechetti et al., 2011; Manjuantha et al., 2012), where the consistency coefficient decreased with the temperature but also increased with SSC.

The combined effect of temperature and SSC on the consistency coefficient in vinasses was well fitted to the exponential model:

$$
K=A \exp \left(\frac{E_{a}}{R T}\right) B X \rightarrow \ln (K)=\beta_{0}+\beta_{1}\left(\frac{1}{T}\right)+\beta_{2} X,
$$

where: $A\left(\mathrm{~Pa} \mathrm{~s}^{\mathrm{n}}\right)$ and $B\left({ }^{\circ} \mathrm{Brix}^{-1}\right)$ are constant parameters and $X$ is the $\mathrm{SSC}\left({ }^{\circ} \mathrm{Brix}\right)$.

The consistency coefficient was altered by both the variables ( $T$ and $X$ ) (Fig. 6). Parameters from the exponential model were calculated using least-square analysis, obtaining the following values: $A=2.12 \times 10^{-10} \mathrm{~Pa} \mathrm{~s}, E_{a}=$ $33.22 \mathrm{~kJ} \mathrm{~mol}^{-1}$, and $B=1.13\left({ }^{\circ} \mathrm{Brix}^{-1}\right)$. The $\mathrm{R}^{2}$ for the exponential model was 0.951 . In the present study, the activation energy is higher than that reported in food systems fitted to the same exponential model (Dak et al., 2008a,b; Vélez and Barbosa, 1997).

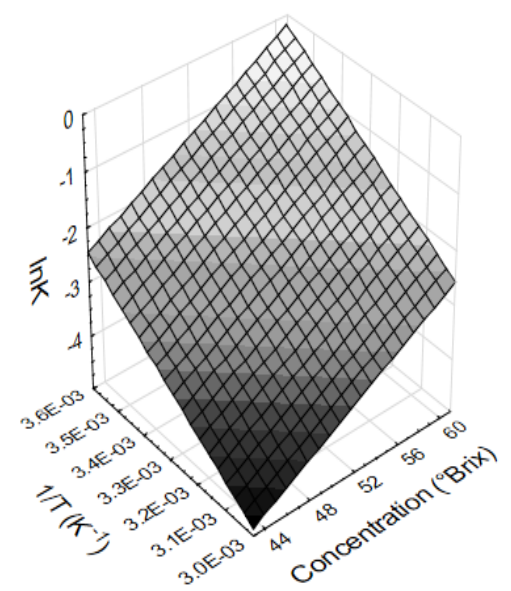

Fig. 6. Dependence of $\ln (K)$ on both the temperature $(T)$ and concentration ( ${ }^{\circ}$ Brix) in vinasses.

The effect of temperature and SSC on the consistency coefficient is opposite because the temperature causes a decrease while SSC causes an increase in the $K$ values. Hence, the more concentrated vinasses required more energy. In contrast, higher temperature process in vinasses required less energy in pumping and mixing industrial process. This 
behaviour has been reported previously in food systems such as concentrated milk, tomato concentrate, and pineapple juice (Dak et al., 2008a,b; Vélez and Barbosa, 1997).

\section{CONCLUSIONS}

1. The experimental results show that the rheological properties of vinasses are controlled by the temperature in the range of 10 to $50^{\circ} \mathrm{C}$ and soluble solids content between 44 and $60^{\circ}$ Brix. Flow curves were well fitted to the power law model, obtaining flow behaviour index values typical of pseudoplastic systems. Pseudoplastic behaviour changes when temperature increases.

2. The consistency coefficient showed an Arrhenius thermal activation. The consistency coefficient decreased and increased with the temperature and soluble solids content, respectively. The results are consistent with the interpretation that the soluble solids content increases the quantity of intermolecular forces within the system, increasing in this way vinasse viscosity. The effect of temperature on the shear stress values (fixing a shear rate value) can also be explained by means of the Arrhenius model.

3. The dependence of the consistency coefficient on both the soluble solids content and temperature was well described by an exponential model with an activation energy value of $33.22 \mathrm{~kJ} \mathrm{~mol}^{-1}$, a value that was higher to that reported in food systems. The present study demonstrates new findings related to the rheological properties of vinasses and could serve for future research in the simulation and design of industrial equipment oriented to the treatment of organic residues.

\section{REFERENCES}

Ahmed O., Sulieman A.B.E., and Elhardallou S.B., 2013. Physicochemical, chemical and microbiological characteristics of vinasse, A by-product from ethanol industry. Am. J. Biochem., 3, 80-83.

Association of Official Analytical Chemists (AOAC), 1990a. Method number: 920.39: Step Official Methods of Analysis, Arlington, VI, USA.

Association of Official Analytical Chemists (AOAC), 1990b. Method number: 934.01: Step Official Methods of Analysis, Arlington, VI, USA.

Association of Official Analytical Chemists (AOAC), 1990c. Method number: 942.05: Step Official Methods of Analysis, Arlington, VI, USA.

Chaves M.A., Baptistia F., Silva J.N., Rodrigues L., and Viana A.D., 2013. A rheological model for Cupuassu (Theobroma grandiflorum ) pulp at different concentrations and temperatures. Int. J. Food Eng., 9, 353-363.

Cortez L.A.B. and Pérez L.E.B., 1997. Experiences on vinasse disposal part III: Combustion of vinasse-\# 6 fuel oil emulsions. Braz. J. Chem. Eng., 14, ISSN: 0104-6632.

Dak M., Verma R.C., and Jaaffrey S.N.A., 2008a. Rheological properties of tomato concentrate. Int. J. Food Prop., 4, 1-19.
Dak M., Verma R.C., and Jain M.K., 2008b. Rheological parameters of pineapple juice. In.t J. Food Prop., 4, 1-19.

Gamboa E.E., Cortes J.M., Perez L.B., Maldonado J.D., Zarate G.H., and Gaviria L.A., 2011. Vinasses: characterization and treatments. Waste Manag. Res., 29, 1235-1250.

Grigelmo N.M., Ibarz-Ribas A., and Martín-Belloso M., 1999. Rheology of peach dietary fibre suspensions. J. Food Eng., 39, 91-99.

Juszczak L., Witczak M., Zięba T., and Fortuna T., 2012. Rheological behaviour of heated potato starch dispersions. Int. Agroph., 26, 381-386.

Kjeldahl J.Z., 1883. New method for the determination of nitrogen in organic bodies. Z. Anal. Chem., 22, 366-382.

Lozano D.C., Velásquez M.M.V., Cantú N.A.V., Mauro M.A., Bianchi V.L., and Romero J.T., 2010. Rheological behaviour of vinasses from a Mexican bioethanol factory. Proc. Int. Soc. Sugar Cane Technol., 27, 1-7.

Manjuantha S.S., Raju P.S., and Bawa A.S., 2012. Rheological behaviour of enzyme clarified Indian gooseberry juice. Int. Agrophys., 26, 145-151.

Mechetti M., López A.R.G., and Balella A., 2011. Propiedades reológicas de melados de caña de azucar. Investigación Desarrollo, 33, 1-8.

Nurul M.I., Azemi B.M.N., and Manan D.M.A., 1999. Rheological behaviour of sago (Metroxylon sagu) starch paste. Food Chem., 64, 501-505.

Prasad K.R., Kumar R.R., and Srivastava S.N., 2008. Design of optimum reponse surface experiments for electro-coagulation of distillery spent wash. Water Air Soil Poll., 191, 5-13.

Pérez L.B., Bezzon G., Gómez E.O., and Cortez L.A.B., 2000. Use of a rotational bench viscometer to study the influence of temperature and agitation speed on vinasse viscosity. Braz. J. Chem Ing., 17, 133-141.

Quek M.C., Chin N.L., and Yusof Y.A., 2013. Modelling of rheological behaviour of soursop juice concentrates using shear rate-temperature-concentration superposition. J. Food Eng., 118, 380-386.

Rao M.A., Okechukwu P.E., Da Silva P.M.S., and Oliveira J.C., 1997. Rheological behavior of heated starch dispersions in excess water: Role of starch granule. Carbohyd. Polym., 33, 273-283.

Santos J.D., Silva A.L.L., Costa J.L., Scheidt G.N., Novak A.C., Sydney E.B., and Soccol C.R., 2013. Development of a vinasse nutritive solution for hydroponics. J. Environ. Manag., 114, 8-12.

Soest P.J. and Wine R.H.J., 1967. Use of detergents in the analysis of fibrous feeds. IV. Determination of plant cell wall constituents. Assoc. Off Agr. Chem., 50, 50-55.

Valencia G.A, Henao A.C.A., and Zapata R.A.V., 2013. Effect of glycerol concentration and temperature on the rheological properties of cassava starch solutions. J. Polym. Eng., 33, 141-148.

Vélez J.F. and Barbosa G.V., 1997. Effect of concentration and temperature on the rheology of concentrated milk. ASAE, 40, 1113-1117. 